\title{
CADANGAN PREMI ASURANSI JOINT-LIFE DENGAN SUKU BUNGA TETAP DAN BERUBAH SECARA STOKASTIK
}

\author{
Ni Komang Sukanasih ${ }^{1 \S}$, I Nyoman Widana ${ }^{2}$, Ketut Jayanegara ${ }^{3}$ \\ ${ }^{1}$ Jurusan Matematika, Fakultas MIPA - Universitas Udayana [Email: nikomangsukanasih@yahoo.com] \\ ${ }^{2}$ Jurusan Matematika, Fakultas MIPA - Universitas Udayana [Email: nwidana@yahoo.com] \\ ${ }^{3}$ Jurusan Matematika, Fakultas MIPA - Universitas Udayana [Email: ketut_jayanegara@yahoo.com] \\ ${ }^{\S}$ Corresponding Author
}

\begin{abstract}
Joint life is an insurance that covered two or more individuals in one policy. This research aims to determine the value and comparison of fixed deposit rate premium and stochastic rate with Vasicek model. It used prospective calculation method. The mortality table in the research used TMI-2011, for participant were couple age 40 and 35 years old with 10 year premium payment. Under this condition the value of constant rate premium and Vasicek rate premium is Rp. 0,1071 and Rp. 0,1043. Besed of this research showed the value of the Vasicek rate premium is smaller than constant rate premium.
\end{abstract}

Keywords: Joint Life Insurance, Premium Reserve, Vasicek, Prospective.

\section{PENDAHULUAN}

Asuransi joint life merupakan asuransi jiwa gabungan yang menanggung dua jiwa atau lebih dalam satu polis. Manfaat yang diperoleh dari asuransi joint life yaitu dibayarkan jika salah satu tertanggung meninggal dunia, dan tertanggung memiliki kewajiban untuk membayar premi dengan sejumlah uang yang dibayarkan ke perusahaan asuransi sesuai dengan kontrak asurani yang telah disepakati (Futami, 1994).

Pendapatan yang diperoleh perusahaan asuransi jiwa dari premi beserta bunganya akan jauh lebih besar dari jumlah uang pertanggungan yang harus dibayarkan oleh perusahaan asuransi kepada pihak tertanggung, kemudian kelebihan dana inilah disimpan sebagai cadangan premi.

Cadangan premi adalah sejumlah dana yang dihimpun oleh perusahaan asuransi yang diperoleh dari selisih nilai tunai pembayaran dan nilai santunan pada waktu pertanggungan sebagai persiapan pembayaran klaim (Sembiring, 1986). Cadangan premi dapat dihitung dengan dua cara yaitu, dengan cara prospektif dan secara retrospektif. Perhitungan cara prospektif adalah perhitungan cadangan premi berdasarkan nilai sekarang dari semua pengeluaran di waktu yang akan datang, dikurangi dengan nilai seka-rang dari semua pendapatan di waktu yang akan datang (Futami, 1993).

Beberapa faktor yang harus diperhatikan dalam perhitungan premi asuransi jiwa yaitu, tingkat angka kematian, biaya perusahaan, dan tingkat suku bunga. Ada dua jenis perhitungan premi asuransi jiwa pada tingkat suku bunga yaitu menggunakan suku bunga konstan dan suku bunga tidak konstan. Selama ini suku bunga yang digunakan untuk perhitungan premi asuransi jiwa adalah menggunakan suku bunga konstan. Suku bunga tidak selalu konstan tetapi, berubah-ubah karena dipengaruhi oleh beberapa faktor yaitu inflasi, penawaran, dan permintaan. Suku bunga yang mengalami perubahan secara tidak menentu dapat dikatakan mengikuti proses stokastik.

Suatu model suku bunga diperlukan untuk dapat menangkap pergerakan suku bunga yang berubah-ubah mengikuti proses stokastik tersebut dan disebut sebagai model suku bunga stokastik (Paul, 2013). Vasicek merupakan salah 
satu model suku bunga stokastik yang sering digunakan untuk perhitungan finansial.

Penelitian terkait mengenai suku bunga stokastik model Vasicek pernah dilakukan oleh Soffan (2011) mengenai premi asuransi jiwa berjangka dengan model Vasicek menggunakan model numerik. Hasil penelitiannya adalah besar nilai suku bunga awal yang digunakan dalam perhitungan premi tidak memengaruhi konvergensi nilai suku bunga menuju tingkat suku bunga rata-rata. Sedangkan oleh Matvejevs (2001) telah menghitung harga premi untuk asuransi joint life dengan tingkat bunga konstan. Berdasarkan uraian tersebut maka peneliti ingin mengetahui nilai dan perbandingan nilai cadangan premi tahunan tingkat suku bunga tetap dengan suku bunga berubah secara stokastik model Vasicek untuk asuransi jiwa joint life menggunakan perhitungan secara prospektif.

Selanjutnya dibahas konsep-konsep yang digunakan dalam perhitungan nilai cadangan premi tahunan tingkat suku bunga tetap dan stokastik model Vasicek untuk asuransi jiwa joint life.

Tingkat bunga untuk menentukan nilai sekarang dari pembayaran yang akan datang, pada bunga majemuk didefinisikan sebagai berikut (Futami, 1993):

$$
v^{t}=\frac{1}{(1+i)^{t}}
$$

Peluang gabungan dari dua orang yang berusia $x$ tahun dan $y$ tahun tetap hidup selama $t$ tahun dinotasikan dengan ${ }_{t} p_{x y}$ dan peluang dari dua orang berusia $x$ tahun dan $y$ tahun yang meninggal dalam jangka waktu $t$ tahun dinotasikan dengan ${ }_{t} q_{x y}$ yang secara berturutturut dinyatakan sebagai:

$$
\begin{aligned}
& { }_{t} p_{x y}={ }_{t} p_{x} \times{ }_{t} p_{y}=\frac{l_{x+t}}{l_{x}} \times \frac{l_{y+t}}{l_{y}}=\frac{l_{x y+t}}{l_{x y}} \\
& { }_{t} q_{x y}=1-{ }_{t} p_{x y}=\frac{l_{x y}-l_{x y+t}}{l_{x y}}
\end{aligned}
$$

Anuitas awal dari anuitas seumur hidup yang meninggal antara usia $x+t$ tahun dinotasikan dengan $\ddot{a}_{x+t}$, dirumuskan sebagai:

$\ddot{a}_{x+t}=\sum_{k=0}^{\infty} v^{k}{ }_{k} p_{x}=\frac{N_{x+t}}{D_{x+t}}$

Anuitas awal pada anuitas yang ditunda dinotasikan dengan ${ }_{t} \mid \ddot{a}_{x}$, dirumuskan sebagai:

$$
{ }_{t} \mid \ddot{a}_{x}=\sum_{k=t}^{\infty} v^{k}{ }_{k} p_{x}=\sum_{n=t}^{\infty} \frac{D_{x+k}}{D_{x}}=\frac{N_{x+t}}{D_{x}}
$$

Nilai sekarang anuitas awal dari anuitas hidup berjangka joint life apabila $x$ dan $y$ tetap hidup dinotasikan dengan $\ddot{a}_{x y: \bar{t} \mid}$, dirumuskan sebagai:

$$
\ddot{a}_{x y: \bar{t}]}=\sum_{k=0}^{t-1} v^{k}{ }_{k} p_{x y}
$$

Besar premi ditentukan dengan prinsip ekuivalensi dan mempunyai persamaan sebagai berikut (Dickson, 2013):

$$
E(L)=0
$$

didefinisikan $L$ sebagai variable random dari nilai tunai benefit yang dibayarkan pihak penanggung (Matvejevs, 2001).

Premi tunggal pure endowment joint life dinotasikan dengan $A_{x y: \bar{t}^{1}}$ dan dirumuskan sebagai:

$$
A_{x y: t{ }^{1}}{ }^{1}=v^{t} \frac{l_{x y+t}}{l_{x y}}=v^{t}{ }_{t} p_{x y}
$$

Premi tunggal asuransi berjangka joint life dinotasikan dengan $A_{x y: \bar{t} \mid}^{1}$ dan dirumuskan sebagai:

$$
A_{x y: \bar{t} \mid}^{1}=\sum_{k=0}^{t-1} v^{k+1}\left({ }_{k} p_{x y}-{ }_{k+1} p_{x y}\right)
$$

Premi tunggal anuitas menaik asuransi joint life dinotasikan dengan $(I A)^{1}{ }_{x y: \bar{t},}, \quad$ dan dirumuskan sebagai:

$(I A)^{1}{ }_{x y: \overline{\mid}]}=\sum_{k=0}^{t-1}(k+1) v^{k+1}\left({ }_{k} p_{x y}-{ }_{k+1} p_{x y}\right)$

Nilai tunai dari pendapatan premi tahunan konstan pada joint life dapat dinyatakan sebagai berikut:

$$
\mathcal{P} \cdot\left(1+v \cdot p_{x y}+v^{2} \cdot p_{x y}+\cdots+v^{t-1} \cdot t-1 p_{x y}\right)=\mathcal{P} \cdot \ddot{a}_{x y: \bar{t} \mid}(11)
$$

Nilai tunai dari benefit dibayarkan oleh pihak penanggung dapat dirumuskan sebagai berikut:

$$
\begin{gathered}
\text { Q.v }{ }^{t} \cdot{ }_{t} p_{x y}+R_{x} \sum_{m=0}^{t-1} \sum_{k=t}^{\infty} v^{k}{ }_{k} p_{x m}\left|q_{y}+R_{y} \sum_{k=0}^{t-1} \sum_{m=t}^{\infty} v^{m}{ }_{m} p_{y k}\right| q_{x} \\
+\mathcal{P} \cdot(I A)^{1}{ }_{x y: t 7} \\
=Q \cdot A_{x y: \bar{t} \mid}{ }^{1}+R_{x \cdot{ }_{t}}\left|\ddot{a}_{x} \cdot{ }_{t} q_{y}+R_{y} \cdot{ }_{t}\right| \ddot{a}_{y} \cdot{ }_{t} q_{x}+\mathcal{P} \cdot(I A)^{1}{ }_{x y: \bar{t} \mid}
\end{gathered}
$$

Menggunakan prinsip ekuivalensi $E(L)=0$, besar preminya adalah: 


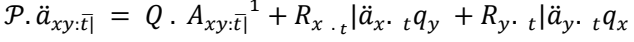

$$
\begin{aligned}
& +\mathcal{P} \text {. }(I A)^{1}{ }_{x y: \bar{t} \mid}
\end{aligned}
$$

Sehingga diperoleh besar nilai premi tahunan yang harus dibayar peserta adalah:

$$
\mathcal{P}=\frac{Q \cdot A_{x y: \bar{t} \mid}{ }^{1}+R_{x \cdot{ }_{t}}\left|\ddot{a}_{x} \cdot{ }_{t} q_{y}+R_{y \cdot{ }_{t}}\right| \ddot{a}_{y} \cdot{ }_{t} q_{x}}{\ddot{a}_{x y: \bar{t} \mid}-(I A)^{1}{ }_{x y: \bar{t} \mid}}
$$

Cadangan premi yang menggunakan perhitungan secara prospektif dimisalkan suatu asuransi seumur hidup dengan pertanggungan sebesar $R p .1$ dengan premi sebesar $\mathcal{P}$ dan didefinisikan ${ }_{t} L$ sebagai variabel kerugian pada tahun ke $-t$ :

${ }_{t} L=v^{K_{x}+1-t}-\mathcal{P} \ddot{a}_{\overline{K_{x}+1-t}}$, dengan $K_{x}>t$

maka besar cadangan pada akhir tahun ke-t adalah sebagai berikut:

$$
\begin{aligned}
{ }_{t} V & =E\left[{ }_{t} L \mid K_{x}>t\right] \\
& =E\left[v^{K_{x}+1-t} \mid K_{x}>t\right]-\mathcal{P} \mathrm{E}\left[\ddot{a}_{\overline{K_{x}+1-t \mid} \mid} \mid K_{x}>t\right] \\
& =A_{x+t}-\mathcal{P} \ddot{a}_{x+t}
\end{aligned}
$$

selanjutnya model Vasicek merupakan model suku bunga stokastik yang memiliki ciri khusus pada tingkat suku bunga akan cenderung kembali ke tingkat suku bunga rata-rata setelah terjadinya penurunan atau peningkatan dan didefinisikan sebagai berikut (Zetun, 2007):

$d r(t)=\kappa[\theta-r(t)] d t+\sigma d W(t), \quad r(0)=r_{0}$

dengan $r, \kappa$, dan $\theta$ suatu konstanta positif.

Ekspektasi nilai tunai pembayaran sebesar satu unit pada saat $k$ dengan tingkat suku bunga mengikuti model Vasicek dinotasikan dengan $\mathrm{P}(k)$ dan didefinisikan sebagai berikut:

$$
\begin{gathered}
\mathrm{P}(k)=\exp \left\{\left(\theta-\frac{\sigma^{2}}{2 \kappa^{2}}\right)(B(k)-k)-\frac{\sigma^{2}}{4 \kappa} B(k)^{2}\right. \\
-r(0) B(k)\}
\end{gathered}
$$

dengan $B(k)=\frac{1-e^{-\kappa k}}{\kappa}$

\section{METODE PENELITIAN}

\section{Jenis dan Sumber Data}

Penelitian ini menggunakan data sekunder yaitu Tabel Mortalitas Indonsia (TMI) 2011, dengan usia peserta sepasang suami istri 40 dan 35 tahun. Masa pertanggungan asuransi jiwa 10 tahun dan tingkat suku bunga yang digunakan adalah rata-rata tingkat suku bunga tahunan Bank Indonesia bulan Januari 2006-Januari 2016.

\section{Metode Analisis Data}

Penelitian ini menggunakan metode perhitungan secara prospektif dan suku bunga tetap serta suku bunga stokastik model Vasicek dengan bantuan software Microsoft Excel dan R i3863.8.0. Adapun langkah-langkah penelitian ini sebagai berikut:

1. Menentukan formula cadangan premi tahunan suku bunga tetap dan suku bunga stokastik model Vasicek pada asuransi jiwa joint life dengan perhitungan secara prospektif.

2. Menghitung nilai tabel mortalitas yang dilanjutkan dengan menghitung nilai tabel mortalitas joint life.

3. Menghitung nilai tabel komutasi tunggal.

4. Menghitung cadangan premi asuransi jiwa joint life suku bunga tetap dengan melakukan simulasi terhadap pihak tertanggung berusia $x$ tahun dan $y$ tahun dalam jangka waktu $t$ tahun sebagai berikut: (a) Menghitung nilai anuitas awal dari anuitas hidup yang ditunda. (b) Menghitung nilai anuitas awal hidup berjangka joint life. (c) Menghitung nilai premi tunggal pure endowment joint life. (d) Menghitung nilai premi tunggal asuransi jiwa berjangka joint life. (e) Menghitung nilai premi tunggal anuitas menaik pada asuransi jiwa joint life. (f) Menghitung nilai premi tahunan konstan pada asuransi jiwa joint life. (g) Menghitung nilai cadangan premi tahunan untuk asuransi jiwa joint life.

5. Estimasi parameter suku bunga stokastik model Vasicek dengan menggunakan metode Maximum Likelihood Estimator (MLE) dan bantuan Software R i386 3.8.0.

6. Menghitung cadangan premi asuransi jiwa joint life suku bunga stokastik model Vasicek dengan melakukan simulasi terhadap pihak tertanggung yang berusia $x$ tahun dan $y$ tahun dalam jangka waktu $t$ tahun sebagai berikut: (a) Menghitung nilai anuitas awal dari anuitas hidup ditunda. (b) Menghitung nilai anuitas awal hidup berjangka joint life. (c) Menghitung nilai premi tunggal pure endowment joint life. (d) Menghitung nilai premi tunggal asuransi jiwa berjangka joint 
life. (e) Menghitung nilai premi tunggal anuitas menaik pada asuransi jiwa joint life. (f) Menghitung nilai premi tahunan konstan pada asuransi jiwa joint life. (g) Menghitung nilai cadangan premi tahunan untuk asuransi jiwa joint life.

7. Membandingkan hasil perhitungan cadangan premi tahunan asuransi jiwa joint life suku bunga tetap dengan suku bunga stokastik model Vasicek.

\section{HASIL DAN PEMBAHASAN}

Kontrak asuransi joint life melibatkan pasangan suami-istri dengan usia berturut-turut $x$ tahun dan $y$ tahun, dengan masa kontrak asuransi adalah $t$ tahun. Pembayaran premi dilakukan setiap $t$ tahun selama $x$ dan $y$ masih hidup pada akhir kontrak dengan tingkat suku bunga konstan setiap tahunnya. Rincian dari uang pertanggungan adalah sebagai berikut (Matvejevs, 2001): (a) Apabila peserta asuransi $x$ dan $y$ masih hidup pada akhir kontrak, maka diberikan uang pertanggungan sebesar $Q$ dan kontrak asuransi berakhir. (b) Apabila salah satu peserta asuransi baik $x$ atau $y$ meninggal selama kontrak, maka premi berikutnya tidak perlu dibayar lagi dan premi yang telah dibayarkan akan dikembalikan semua ke peserta yang masih hidup baik $x$ atau $y$ pada akhir tahun kematian, dan diberikan uang pertanggungan sebesar $R_{x}$ atau $R_{y}$ yang masih hidup pada akhir kontrak selama seumur hidup. (c) Jika $x$ dan $y$ meninggal ditahun yang sama sebelum masa kontrak berakhir pada $t$ tahun, maka ahli waris menerima uang pertanggungan sejumlah premi yang telah dibayarkan dan kontrak berakhir.

Berdasarkan kontrak asuransi tersebut maka pada persamaan (15) yaitu:

$$
{ }_{t} V=A_{x+t}-P \ddot{a}_{x+t}
$$

dimodifikasi formula cadangan premi asuransi joint life suku bunga tetap menggunakan metode perhitungan secara prospektif dengan kasus sebagai berikut:

Kasus pertama untuk cadangan premi apabila $x$ hidup $y$ meninggal pada tahun $\mathrm{ke}-t$ untuk $t \leq 10$ maka dari persamaan (15) dengan $R_{x}$ merupakan uang pertanggungan diberikan kepada $x$ apabila $y$ meninggal, dikali dengan ${ }_{10-t} \mid \ddot{a}_{x+t}$ yang merupakan nilai anuitas peserta berusia $x+t$ tahun dimulai dari periode $10-t$ sebagai berikut:

$$
\begin{aligned}
{ }_{t} V & =R_{x} \times{ }_{10-t} \mid \ddot{a}_{x+t} \\
& =R_{x} \times\left(\frac{N_{x+10}}{D_{x+t}}\right)
\end{aligned}
$$

Kasus kedua untuk cadangan premi apabila $x$ meninggal $y$ hidup pada tahun ke- $t$ untuk $t \leq 10$ maka dari persamaan (15) dengan $R_{y}$ merupakan uang pertanggungan diberikan kepada $y$ apabila $x$ meninggal, dikali dengan ${ }_{10-t} \mid \ddot{a}_{y+t}$ yang merupakan nilai anuitas peserta berusia $y+t$ tahun dimulai dari periode $10-t$ sebagai berikut:

$$
\begin{aligned}
{ }_{t} V & =R_{y} \times{ }_{10-t} \mid \ddot{a}_{y+t} \\
& =R_{y} \times\left(\frac{N_{y+10}}{D_{y+t}}\right)
\end{aligned}
$$

Kasus ketiga untuk cadangan premi apabila $x$ hidup $y$ hidup pada akhir tahun ke- $t$ untuk $t \leq 10$ maka dari persamaan (15) dengan $R_{x 10-t} \mid \ddot{a}_{x+t}$ merupakan uang pertanggungan dikalikan dengan nilai anuitas peserta berusia $x+t$ tahun dimulai dari periode $10-t$ yang diberikan oleh perusahaan apabila $y$ meninggal sebelum akhir tahun ke $-t$ dan $x$ masih tetap hidup sampai akhir tahun ke-t, ditambah dengan $R_{y \text { 10- }} \mid \ddot{a}_{y+t}$ yang merupakan uang pertanggungan dikalikan dengan nilai anuitas peserta berusia $y+t$ tahun dimulai dari periode $10-t$ yang diberikan apabila $x$ meninggal sebelum akhir tahun ke- $t$ dan y masih tetap hidup sampai akhir tahun ke-t, ditambah dengan $\left(Q \times\left(v^{10-n} \times \frac{l_{x+10} l_{y+10}}{l_{x+t} l_{y+t}}\right)\right)$ dengan $Q$ yang merupakan uang pertanggungan yang diberikan apabila $x$ dan $y$ masih hidup sampai akhir tahun ke- $t$ dikali dengan peluang orang yang berusia $x$ dan $y$ tahun tetap hidup selama $t$ tahun dinotasikan dngan $v^{10-n} \times \frac{l_{x+10} l_{y+10}}{l_{x+t} l_{y+t}}$, lalu ditambah dengan $\mathcal{P} \sum_{k=0}^{10-t-1} v^{k+1}(k+t+$ 1) $\left({ }_{k} p_{x+t ; y+t}-{ }_{k+1} p_{x+t ; y+t}\right)$ merupakan premi 
bersih tahunan yang dibayarkan pada permulaan tahun $\mathrm{ke}-t$ yang dibungakan selama $v^{k+1}$ dikurangi dengan $\mathcal{P} . \ddot{a}_{x+t ; y+t}$ yang merupakan uang pertanggungan yang dibayarkan pada akhir tahun ke $-t$. Sehingga diperoleh formula cadangan premi sebagai beriku:

$$
\begin{aligned}
{ }_{t} V= & R_{x} \times\left(\frac{N_{x+10}}{D_{x+t}}\right)+R_{y} \times\left(\frac{N_{y+10}}{D_{y+t}}\right)+ \\
& \left(Q\left(v^{10-t} \times \frac{l_{x+10} l_{y+10}}{l_{x+t} l_{y+t}}\right)\right)+ \\
& \left(\mathcal{P} \sum_{k=0}^{10-t-1} v^{k+1}(k+t+1)\left({ }_{k} p_{x+t ; y+t}-{ }_{k+t} p_{x+t ; y+t}\right)\right) \\
& -\mathcal{P} \cdot \ddot{a}_{x+t ; y+t}
\end{aligned}
$$

Selanjutnya, dicari formula cadangan premi untuk asuransi joint life yang benefitnya dibayarkan pada saat salah satu peserta asuransi baik $x$ atau $y$ masih hidup di akhir tahun $\mathrm{ke}-t+1$ berbeda dengan cadangan premi akhir tahun ke $-t$ karena pada tahun $\mathrm{ke}-t+1$ sudah tidak ada pembayaran premi lagi, maka diperoleh:

Kasus keempat untuk cadangan premi apabila $x$ hidup $y$ meninggal pada akhir tahun ke $-t+1$ untuk $t>10$ maka dari persamaan (15) dengan $R_{x}$ merupakan uang pertanggungan dikalikan dengan nilai anuitas awal dari anuitas seumur hidup yang mencapai usia $x+t$ tahun di notasikan dengan $\ddot{a}_{x+t}$, yang diberikan apabila $y$ meninggal dunia sebelum akhir tahun ke $-t$ dan $x$ masih hidup selama seumur hidup. Sehingga diperoleh formula cadangan premi sebagai berikut:

$$
\begin{aligned}
{ }_{t} V & =R_{x} \times \ddot{a}_{x+t} \\
& =R_{x} \times\left(\frac{N_{x+t}}{D_{x+t}}\right)
\end{aligned}
$$

Dan kasus kelima untuk cadangan premi apabila $x$ meninggal $y$ hidup pada akhir tahun ke $-t+1$ untuk $t>10$ maka dari persamaan (15) dengan $R_{y}$ merupakan uang pertanggungan dikalikan dengan nilai anuitas awal dari anuitas seumur hidup yang mencapai usia $y+t$ tahun di notasikan dengan $\ddot{a}_{y+t}$, yang diberikan apabila $x$ meninggal dunia sebelum akhir tahun ke $-t$ dan $y$ masih hidup selama seumur hidup. Sehingga diperoleh formula cadangan premi sebagai berikut:

$$
\begin{aligned}
{ }_{t} V & =R_{y} \ddot{a}_{y+t} \\
& =R_{y} \times\left(\frac{N_{y+t}}{D_{y+t}}\right)
\end{aligned}
$$

Formula cadangan premi suku bunga stokastik model Vasicek memiliki formula yang sama dengan formula cadangan premi suku bunga tetap. Perbedaan formula cadangan premi suku bunga Vasicek dan formula cadangan premi suku bunga tetap adalah faktor diskonto pada suku bunga tetap yaitu $v^{k}$ disubsitusikan oleh $\mathrm{P}(k)$ pada suku bunga Vasicek. Penjabaran formula cadangan premi dengan suku bunga Vasicek adalah sebagai berikut:

Kasus pertama untuk cadangan premi apabila $x$ hidup $y$ meninggal pada akhir tahun ke $-t$ untuk $t \leq 10$ yaitu:

$$
\begin{aligned}
{ }_{t} V & =R_{x} \times{ }_{10-t} \mid \ddot{a}_{x+t} \\
& =\frac{R_{x}}{\mathrm{P}(k)} \times\left(\frac{\mathrm{P}(10) l_{x+10}+\mathrm{P}(11) l_{x+11}+\cdots+\mathrm{P}(71) \cdot l_{x+71}}{l_{x+t}}\right)
\end{aligned}
$$

Kasus kedua untuk cadangan premi apabila $x$ meninggal $y$ hidup pada akhir tahun ke $-t$ untuk $t \leq 10$ yaitu:

$$
\begin{aligned}
{ }_{t} V & =R_{y} \times{ }_{10-t} \mid \ddot{a}_{y+t} \\
& =\frac{R_{y}}{\mathrm{P}(k)} \times\left(\frac{\mathrm{P}(10) l_{y+10}+\mathrm{P}(11) l_{y+11}+\cdots+\mathrm{P}(71) \cdot l_{y+71}}{l_{y+t}}\right)
\end{aligned}
$$

Kasus ketiga untuk cadangan premi apabila $x$ dan $y$ hidup pada akhir tahun ke- $t$ untuk $t \leq 10$ yaitu:

$$
\begin{aligned}
{ }_{t} V= & \frac{R_{x}}{\mathrm{P}(k)} \times\left(\frac{\mathrm{P}(10) l_{x+10}+\mathrm{P}(11) l_{x+11}+\cdots+\mathrm{P}(71) \cdot l_{x+71}}{l_{x+t}}\right) \\
& +\frac{R_{y}}{\mathrm{P}(k)} \times\left(\frac{\mathrm{P}(10) l_{y+10}+\mathrm{P}(11) l_{y+11}+\cdots+\mathrm{P}(71) \cdot l_{y+71}}{l_{y+t}}\right) \\
& +\mathrm{P}(10-k) \cdot Q \frac{l_{x+10} l_{y+10}}{l_{x+t} l_{y+t}}+\mathcal{P} \sum_{k=0}^{10-t-1} \mathrm{P}(k+1)(k+t+1) \\
& \left({ }_{k} p_{x+t ; y+t}-{ }_{k+t} p_{x+t ; y+t}\right)-\mathcal{P} \cdot \ddot{a}_{x+t ; y+t}
\end{aligned}
$$

Selanjutnya, dicari formula cadangan premi untuk asuransi joint life yang benefitnya dibayarkan pada saat salah satu peserta asuransi baik $x$ atau $y$ masih hidup di akhir tahun ke $-t+1$ berbeda dengan cadangan premi akhir tahun ke $-t$ karena pada tahun ke $-t+1$ sudah tidak ada pembayaran premi lagi, maka diperoleh:

Kasus keempat untuk cadangan premi apabila $x$ hidup $y$ meninggal pada akhir tahun ke $-t+1$ untuk $t>10$ yaitu: 


$$
\begin{aligned}
{ }_{t} V & =R_{x} \times \ddot{a}_{x+t} \\
& =R_{x} \times\left(\frac{\sum_{k=11}^{71} \mathrm{P}(k) l_{x+t}}{\mathrm{P}(k) l_{x+t}}\right)
\end{aligned}
$$

Kasus kelima untuk cadangan premi apabila $x$ meninggal dan $y$ hidup pada akhir tahun ke $-t+1$ untuk $t>10$ yaitu:

$$
\begin{aligned}
{ }_{t} V & =R_{y} \times \ddot{a}_{y+t} \\
& =R_{y} \times\left(\frac{\sum_{k=11}^{71} \mathrm{P}(k) l_{y+t}}{\mathrm{P}(k) l_{y+t}}\right)
\end{aligned}
$$

Pada penelitian ini diberikan sebuah contoh kasus yaitu misalkan usia peserta mulai mengikuti asuransi ini adalah usia suami $x=40$ tahun dan usia istri $y=35$ tahun. Masa pembayaran premi 10 tahun selama $x$ dan $y$ masih hidup pada akhir kontrak, dengan tingkat suku bunga adalah konstan yaitu 6,5\% dan besar uang pertanggungan yang diberikan perusahaan asuransi kepada peserta asuransi sebagai berikut: (a) apabila kedua peserta asuransi masih hidup pada akhir kontrak, maka diberikan uang pertanggungan sebesar $\operatorname{Rp} .1(Q=1)$ dan kontrak asuransi berakhir. (b) Apabila salah satu peserta asuransi baik suami atau istri meninggal selama kontrak, maka premi berikutnya tidak perlu dibayar lagi dan premi yang telah dibayarkan akan dikembalikan semua ke peserta yang masih hidup baik suami atau istri pada akhir tahun kematian, dan diberikan uang pertanggungan sebesar $R p .1\left(R_{x}=1\right)$ atau $R p .1\left(R_{y}=1\right)$ ke peserta yang masih hidup pada akhir kontrak selama seumur hidup. (c) Jika suami dan istri meninggal di tahun yang sama sebelum masa kontrak berakhir pada $t$ tahun, maka ahli waris akan menerima uang pertanggungan sejumlah premi yang telah dibayarkan dan kontrak berakhir.

Berdasarkan persamaan (1) dan (17) dapat dilihat nilai suku bunga tetap dan suku bunga Vasicek pada tabel 1.

Berdasarkan persamaan (14) yang merupakan nilai premi tahunan suku bunga tetap yaitu:

$$
\begin{aligned}
\mathcal{P} & =\frac{R p \times 1 \cdot A_{x y: \bar{t}^{1}}+R p .1 \times{ }_{\cdot t}\left|\ddot{a}_{x} \cdot{ }_{t} q_{y}+R p \cdot 1 \times{ }_{t}\right| \ddot{a}_{y} \cdot{ }_{t} q_{x}}{\ddot{a}_{x y: \bar{t} \mid}-(I A)^{1}{ }_{x y: \bar{t} \mid}} \\
& =\frac{R p .1 \times 0,5120+R p \cdot 0,0739+R p \cdot 0,2077}{7,4071} \\
& =R p .0,1071
\end{aligned}
$$

dan nilai premi suku bunga stokastik model Vasicek untuk asuransi jiwa joint life adalah:

$$
\begin{aligned}
\mathcal{P} & =\frac{R p .1 \times \mathrm{P}(10)_{10} p_{x y}+R p .1 \times \sum_{t=0}^{9}{ }_{t} q_{x}+R p .1 \times \sum_{t=0}^{9}{ }_{t} q_{y}}{\mathrm{P}(k)_{k} p_{x y}-(I A)^{1}{ }_{x y . \bar{t}}} \\
& =\frac{R p .1 \times 0,4987+R p .0,0793+R p .0,1977}{7,3369}=R p .0,1057
\end{aligned}
$$

Tabel 1. Suku Bunga Tetap $\left(v^{k}\right)$ dan Suku Bunga Vasicek $\mathrm{P}(k)$ dengan Bunga (6,5\%).

\begin{tabular}{|c|c|c|c|c|c|}
\hline$t / k$ & $\left(v^{k}\right)$ & $\mathrm{P}(k)$ & $t / k$ & $\left(v^{k}\right)$ & $\mathrm{P}(k)$ \\
\hline 0 & 1,0000 & 1,0000 & 36 & 0,1036 & 0,0939 \\
\hline 1 & 0,9390 & 0,9369 & 37 & 0,0973 & 0,0879 \\
\hline 2 & 0,8817 & 0,8776 & 38 & 0,0914 & 0,0823 \\
\hline 3 & 0,8278 & 0,8219 & 39 & 0,0858 & 0,0771 \\
\hline 4 & 0,7773 & 0,7697 & 40 & 0,0805 & 0,0722 \\
\hline 5 & 0,7299 & 0,7208 & 41 & 0,0756 & 0,0676 \\
\hline 6 & 0,6853 & 0,6749 & 42 & 0,0710 & 0,0633 \\
\hline 7 & 0,6435 & 0,6320 & 43 & 0,0667 & 0,0593 \\
\hline 8 & 0,6042 & 0,5918 & 44 & 0,0626 & 0,0555 \\
\hline 9 & 0,5674 & 0,5541 & 45 & 0,0588 & 0,0520 \\
\hline 10 & 0,5327 & 0,5189 & 46 & 0,0552 & 0,0487 \\
\hline 11 & 0,5002 & 0,4859 & 47 & 0,0518 & 0,0456 \\
\hline 12 & 0,4697 & 0,4549 & 48 & 0,0487 & 0,0427 \\
\hline 13 & 0,4410 & 0,4260 & 49 & 0,0457 & 0,0400 \\
\hline 14 & 0,4141 & 0,3989 & 50 & 0,0429 & 0,0374 \\
\hline 15 & 0,3888 & 0,3735 & 51 & 0,0403 & 0,0350 \\
\hline 16 & 0,3651 & 0,3497 & 52 & 0,0378 & 0,0328 \\
\hline 17 & 0,3428 & 0,3275 & 53 & 0,0355 & 0,0307 \\
\hline 18 & 0,3219 & 0,3067 & 54 & 0,0334 & 0,0288 \\
\hline 19 & 0,3022 & 0,2871 & 55 & 0,0313 & 0,0269 \\
\hline 20 & 0,2838 & 0,2689 & 56 & 0,0294 & 0,0252 \\
\hline 21 & 0,2665 & 0,2518 & 57 & 0,0276 & 0,0236 \\
\hline 22 & 0,2502 & 0,2357 & 58 & 0,0259 & 0,0221 \\
\hline 23 & 0,2349 & 0,2207 & 59 & 0,0243 & 0,0207 \\
\hline 24 & 0,2206 & 0,2067 & 60 & 0,0229 & 0,0194 \\
\hline 25 & 0,2071 & 0,1935 & 61 & 0,0215 & 0,0182 \\
\hline 26 & 0,1945 & 0,1812 & 62 & 0,0202 & 0,0170 \\
\hline 27 & 0,1826 & 0,1697 & 63 & 0,0189 & 0,0159 \\
\hline 28 & 0,1715 & 0,1589 & 64 & 0,0178 & 0,0149 \\
\hline 29 & 0,1610 & 0,1488 & 65 & 0,0167 & 0,0140 \\
\hline 30 & 0,1512 & 0,1393 & 66 & 0,0157 & 0,0131 \\
\hline 31 & 0,1420 & 0,1305 & 67 & 0,0147 & 0,0122 \\
\hline 32 & 0,1333 & 0,1222 & 68 & 0,0138 & 0,0115 \\
\hline 33 & 0,1252 & 0,1144 & 69 & 0,0130 & 0,0107 \\
\hline 34 & 0,1175 & 0,1071 & 70 & 0,0122 & 0,0100 \\
\hline 35 & 0,1103 & 0,1003 & 71 & 0,0114 & 0,0094 \\
\hline$D a t a$ & & & \\
\hline
\end{tabular}

Data diolah: Tahun 2017

Selanjutnya nilai dan perbandingan hasil cadangan premi asuransi jiwa joint life suku bunga tetap dan suku bunga stokastik model Vasicek dengan menggunakan perhitungan 
secara prospektif untuk usia peserta $x=40$ tahun dan $y=35$ tahun dengan menggunakan formula yang telah diperoleh sebelumnya dapat dilihat pada tabel berikut:

Tabel 2 Cadangan Premi $x$ Hidup $y$ Meninggal untuk $t \leq 10$.

\begin{tabular}{|c|c|c|}
\hline $\begin{array}{l}\text { Jangka } \\
\text { Waktu }(t)\end{array}$ & $\begin{array}{c}{ }^{V} \\
\text { (Suku Bunga Tetap) } \\
\text { (Rp.) }\end{array}$ & $\begin{array}{c}t V \\
\text { (Suku Bunga } \\
\text { Vasicek) (Rp.) }\end{array}$ \\
\hline 1 & 6,9772 & 6.6336 \\
\hline 2 & 7,4438 & 7.0945 \\
\hline 3 & 7,9432 & 7.5900 \\
\hline 4 & 8,4781 & 8.1227 \\
\hline 5 & 9,0514 & 8.6955 \\
\hline 6 & 9,6667 & 9.3120 \\
\hline 7 & 10,3279 & 9.9762 \\
\hline 8 & 11,0393 & 10.6928 \\
\hline 9 & 11,8057 & 11.4668 \\
\hline 10 & 12,6326 & 12.3039 \\
\hline
\end{tabular}

Data diolah: Tahun 2017

Berdasarkan tabel 2 diperoleh hasil nilai cadangan premi $x$ hidup $y$ meninggal suku bunga tetap dengan suku bunga Vasicek samasama mengalami peningkatan pada cadangan premi tahunan pertama sampai tahun kesepuluh dan nilai cadangan premi suku bunga Vasicek lebih kecil dibandingkan suku bunga tetap.

Tabel 3 Cadangan Premi $x$ Meninggal $y$ Hidup untuk $t \leq 10$.

\begin{tabular}{|c|c|c|}
\hline $\begin{array}{l}\text { Jangka } \\
\text { Waktu } \\
(t)\end{array}$ & $\begin{array}{c}t^{V} \\
\text { (Suku Bunga Tetap) } \\
\text { (Rp.) }\end{array}$ & $\begin{array}{c}{ }^{V} \\
\text { (Suku Bunga } \\
\text { Vasicek) (Rp.) }\end{array}$ \\
\hline 1 & 7,9073 & 7,4860 \\
\hline 2 & 8,4275 & 7,9980 \\
\hline 3 & 8,9828 & 8,5470 \\
\hline 4 & 9,5756 & 9,1353 \\
\hline 5 & 10,2087 & 9,7656 \\
\hline 6 & 10,8846 & 10,4407 \\
\hline 7 & 11,6067 & 11,1640 \\
\hline 8 & 12,3786 & 11,9393 \\
\hline 9 & 13,2041 & 12,7707 \\
\hline 10 & 14,0870 & 13,6624 \\
\hline
\end{tabular}

Data diolah: Tahun 2017

Berdasarkan tabel 3 diperoleh hasil nilai cadangan premi $x$ meninggal $y$ hidup suku bunga tetap dengan suku bunga Vasicek samasama mengalami peningkatan pada cadangan premi tahunan pertama sampai tahun kesepuluh dan nilai cadangan premi suku bunga Vasicek lebih kecil dibandingkan suku bunga tetap.

Tabel 4. Cadangan Premi $x$ dan $y$ Hidup untuk $t \leq 10$

\begin{tabular}{|c|c|c|}
\hline $\begin{array}{c}\text { Jangka } \\
\text { Waktu } \\
(t)\end{array}$ & $\begin{array}{c}{ }^{V} \\
\text { (Suku Bunga } \\
\text { Tetap) (Rp.) }\end{array}$ & $\begin{array}{c}{ }^{V} \\
\text { (Suku Bunga } \\
\text { Vasicek) (Rp.) }\end{array}$ \\
\hline 1 & 13,4480 & 13.3929 \\
\hline 2 & 14,4903 & 14.3413 \\
\hline 3 & 15,6114 & 15.3708 \\
\hline 4 & 16,8179 & 16.4875 \\
\hline 5 & 18,1186 & 17.6997 \\
\hline 6 & 19,5230 & 19.0166 \\
\hline 7 & 21,0425 & 20.4412 \\
\hline 8 & 22,6908 & 22.0126 \\
\hline 9 & 24,4831 & 23.7205 \\
\hline 10 & 26,8060 & 25.5900 \\
\hline
\end{tabular}

Data diolah: Tahun 2017

Berdasarkan tabel 4 diperoleh hasil nilai cadangan premi $x$ dan $y$ hidup suku bunga tetap dan suku bunga Vasicek sama-sama mengalami peningkatan pada cadangan premi tahunan pertama sampai tahun kesepuluh dan nilai cadangan premi suku bunga Vasicek lebih kecil dibandingkan suku bunga tetap.

Tabel 5. Cadangan Premi $x$ Hidup $y$ Meninggal untuk $t>10$

\begin{tabular}{|c|c|c|c|c|c|}
\hline $\begin{array}{c}\text { Jangka } \\
\text { Waktu } \\
(t)\end{array}$ & $\begin{array}{c}{ }_{\boldsymbol{t}} \boldsymbol{V} \\
\text { (Suku } \\
\text { Bunga } \\
\text { Tetap) } \\
\text { (Rp.) } \\
\end{array}$ & $\begin{array}{c}{ }_{\boldsymbol{t}}^{\boldsymbol{V}} \\
\text { (Suku } \\
\text { Bunga } \\
\text { Vasicek) } \\
\text { (Rp.) }\end{array}$ & $\begin{array}{c}\text { Jangka } \\
\text { Waktu } \\
(t)\end{array}$ & $\begin{array}{c}{ }_{t} \boldsymbol{V} \\
\text { (Suku } \\
\text { Bunga } \\
\text { Tetap) } \\
\text { (Rp.) } \\
\end{array}$ & $\begin{array}{c}\boldsymbol{t}^{\boldsymbol{V}} \\
\text { (Suku } \\
\text { Bunga } \\
\text { Vasicek) } \\
\text { (Rp.) }\end{array}$ \\
\hline 11 & 12,4557 & 12,1373 & 42 & 4,9329 & 4,8894 \\
\hline 12 & 12,2759 & 11,9677 & 43 & 4,6848 & 4,6458 \\
\hline 13 & 12,0933 & 11,7955 & 44 & 4,4434 & 4,4086 \\
\hline 14 & 11,9077 & 11,6202 & 45 & 4,2098 & 4,1788 \\
\hline 15 & 11,7189 & 11,4416 & 46 & 3,9861 & 3,9585 \\
\hline 16 & 11,5264 & 11,2593 & 47 & 3,7742 & 3,7497 \\
\hline 17 & 11,3297 & 11,0729 & 48 & 3,5753 & 3,5535 \\
\hline 18 & 11,1282 & 10,8816 & 49 & 3,3907 & 3,3713 \\
\hline 19 & 10,9211 & 10,6847 & 50 & 3,2206 & 3,2034 \\
\hline 20 & 10,7075 & 10,4814 & 51 & 3,0656 & 3,0502 \\
\hline 21 & 10,4871 & 10,2713 & 52 & 2,9190 & 2,9053 \\
\hline 22 & 10,2599 & 10,0542 & 53 & 2,7805 & 2,7683 \\
\hline 23 & 10,0261 & 9,8306 & 54 & 2,6501 & 2,6393 \\
\hline 24 & 9,7863 & 9,6009 & 55 & 2,5290 & 2,5194 \\
\hline 25 & 9,5411 & 9,3657 & 56 & 2,4190 & 2,4104 \\
\hline 26 & 9,2914 & 9,1258 & 57 & 2,3129 & 2,3053 \\
\hline 27 & 9,0371 & 8,8812 & 58 & 2,2114 & 2,2046 \\
\hline 28 & 8,7778 & 8,6313 & 59 & 2,1156 & 2,1095 \\
\hline 29 & 8,5134 & 8,3762 & 60 & 2,0279 & 2,0225 \\
\hline 30 & 8,2425 & 8,1145 & 61 & 1,9539 & 1,9491 \\
\hline 31 & 7,9668 & 7,8477 & 62 & 1,8811 & 1,8768 \\
\hline 32 & 7,6866 & 7,5761 & 63 & 1,8095 & 1,8058 \\
\hline 33 & 7,4072 & 7,3050 & 64 & 1,7393 & 1,7360 \\
\hline 34 & 7,1276 & 7,0334 & 65 & 1,6704 & 1,6675 \\
\hline 35 & 6,8468 & 6,760 & 66 & 1,6026 & 1,6001 \\
\hline 36 & 6,5652 & 6,4860 & 67 & 1,5353 & 1,5332 \\
\hline 37 & 6,2828 & 6,2105 & 68 & 1,4663 & 1,4646 \\
\hline 38 & 6,0015 & 5,9358 & 69 & 1,3880 & 1,3867 \\
\hline 39 & 5,7240 & 5,6645 & 70 & 1,2722 & 1,2714 \\
\hline 40 & 5,4528 & 5,3990 & 71 & 1,0000 & 1,0000 \\
\hline 41 & 5,1882 & 5,1398 & & & \\
\hline
\end{tabular}

Data diolah: Tahun 2017 
Berdasarkan tabel 5 diperoleh hasil nilai cadangan premi $x$ hidup $y$ meninggal suku bunga tetap dengan suku bunga Vasicek samasama mengalami penurunan pada cadangan premi tahun kesebelas sampai tahun ketujuh puluh satu dan nilai cadangan premi suku bunga Vasicek lebih kecil dibandingkan suku bunga tetap.

Tabel 6. Cadangan Premi untuk $x$ Meninggal $y$ Hidup untuk $t>10$.

\begin{tabular}{|c|c|c|c|c|c|}
\hline $\begin{array}{c}\text { Jangka } \\
\text { Waktu } \\
(t)\end{array}$ & $\begin{array}{c}{ }_{t}^{\boldsymbol{V}} \\
(\text { Suku } \\
\text { Bunga } \\
\text { Tetap)(Rp.) }\end{array}$ & $\begin{array}{c}{ }_{t} \boldsymbol{V} \\
\text { (Suku } \\
\text { Bunga } \\
\text { Vasicek) } \\
\text { (Rp.) }\end{array}$ & $\begin{array}{c}\text { Jangka } \\
\text { Waktu } \\
(t)\end{array}$ & $\begin{array}{c}{ }_{t}^{\boldsymbol{V}} \\
\text { (Suku } \\
\text { Bunga } \\
\text { Tetap) } \\
\text { (Rp) }\end{array}$ & $\begin{array}{c}{ }^{t} \boldsymbol{V} \\
\text { (Suku } \\
\text { Bunga } \\
\text { Vasicek) } \\
\text { (Rp.) }\end{array}$ \\
\hline 11 & 13,9646 & 13,5489 & 42 & 7,6084 & 7,5001 \\
\hline 12 & 13,8370 & 13,4304 & 43 & 7,3305 & 7,2304 \\
\hline 13 & 13,7041 & 13,3069 & 44 & 7,0502 & 6,9579 \\
\hline 14 & 13,5662 & 13,1785 & 45 & 6,7676 & 6,6829 \\
\hline 15 & 13,4232 & 13,0450 & 46 & 6,4826 & 6,4051 \\
\hline 16 & 13,2750 & 12,9066 & 47 & 6,2035 & 6,1328 \\
\hline 17 & 13,1220 & 12,7635 & 48 & 5,9320 & 5,8676 \\
\hline 18 & 12,9646 & 12,6161 & 49 & 5,6653 & 5,6068 \\
\hline 19 & 12,8036 & 12,4651 & 50 & 5,4042 & 5,3512 \\
\hline 20 & 12,6394 & 12,3109 & 51 & 5,1501 & 5,1023 \\
\hline 21 & 12,4716 & 12,1533 & 52 & 4,8953 & 4,8524 \\
\hline 22 & 12,2996 & 11,9915 & 53 & 4,6556 & 4,6171 \\
\hline 23 & 12,1219 & 11,8241 & 54 & 4,4308 & 4,3962 \\
\hline 24 & 11,9375 & 11,6500 & 55 & 4,2216 & 4,1906 \\
\hline 25 & 11,7455 & 11,4685 & 56 & 4,0197 & 3,9920 \\
\hline 26 & 11,5452 & 11,2787 & 57 & 3,7943 & 3,7700 \\
\hline 27 & 11,3367 & 11,0809 & 58 & 3,5620 & 3,5408 \\
\hline 28 & 11,1202 & 10,8752 & 59 & 3,3370 & 3,3186 \\
\hline 29 & 10,8984 & 10,6639 & 60 & 3,1302 & 3,1143 \\
\hline 30 & 10,6713 & 10,4475 & 61 & 2,9581 & 2,9440 \\
\hline 31 & 10,4392 & 10,2259 & 62 & 2,8166 & 2,8041 \\
\hline 32 & 10,2023 & 9,9994 & 63 & 2,7142 & 2,7031 \\
\hline 33 & 9,9611 & 9,7684 & 64 & 2,5776 & 2,5679 \\
\hline 34 & 9,7156 & 9,5331 & 65 & 2,4266 & 2,4183 \\
\hline 35 & 9,4664 & 9,2939 & 66 & 2,2758 & 2,2689 \\
\hline 36 & 9,2121 & 9,0494 & 67 & 2,1202 & 2,1148 \\
\hline 37 & 8,9535 & 8,8004 & 68 & 1,9517 & 1,9475 \\
\hline 38 & 8,6912 & 8,5475 & 69 & 1,7512 & 1,7484 \\
\hline 39 & 8,4252 & 8,2907 & 70 & 1,4734 & 1,4721 \\
\hline 40 & 8,1559 & 8,0304 & 71 & 1,0000 & 1,0000 \\
\hline 41 & 7,8836 & 7,7668 & & & \\
\hline
\end{tabular}

Data diolah: Tahun 2017

Berdasarkan tabel 6 diperoleh hasil nilai cadangan premi $x$ meninggal $y$ hidup suku bunga tetap dengan suku bunga Vasicek samasama mengalami penurunan pada cadangan premi tahun kesebelas sampai tahun ketujuh puluh satu dan nilai cadangan premi suku bunga
Vasicek lebih kecil dibandingkan suku bunga tetap.

\section{SIMPULAN DAN SARAN}

\section{Simpulan}

Berdasarkan hasil dan pembahasan dapat disimpulkan bahwa formula cadangan premi asuransi jiwa joint life dengan perhitungan secara prospektif untuk suku bunga tetap dan suku bunga stokastik model Vasicek sebagai berikut:

Cadangan premi apabila $x$ hidup $y$ meninggal pada akhir tahun $\mathrm{ke}-t$ :

$$
\begin{aligned}
V & =R_{x} \times{ }_{10-t} \mid \ddot{a}_{x+t} \\
& =R_{x} \times\left(\frac{N_{x+10}}{D_{x+t}}\right)
\end{aligned}
$$

Cadangan premi apabila $x$ meninggal $y$ hidup pada akhir tahun ke- $t$ :

$$
\begin{aligned}
V & =R_{y} \times{ }_{10-t} \mid \ddot{a}_{y+t} \\
& =R_{y} \times\left(\frac{N_{y+10}}{D_{y+t}}\right)
\end{aligned}
$$

Cadangan premi apabila $x$ hidup $y$ hidup pada akhir tahun ke- $t$ :

$$
\begin{aligned}
{ }_{t} V & =R_{x} \times\left(\frac{N_{x+10}}{D_{x+t}}\right)+R_{y} \times\left(\frac{N_{y+10}}{D_{y+t}}\right)+Q \times v^{10-t} \frac{l_{x+10} l_{y+10}}{l_{x+t} l_{y+t}} \\
+\mathcal{P} & \sum_{k=0}^{10-t-1} v^{k+1}(k+t+1)\left({ }_{k} p_{x+t ; y+t}-{ }_{k+1} p_{x+t ; y+t}\right)-\mathcal{P} \times\left(\frac{N_{x y+t}}{D_{x y+t}}\right)
\end{aligned}
$$

Cadangan premi apabila $x$ hidup $y$ meninggal pada akhir tahun ke- $t+1$ :

$$
\begin{aligned}
{ }_{t} V & =R_{x} \times \ddot{a}_{x+t} \\
& =R_{x} \times\left(\frac{N_{x+t}}{D_{x+t}}\right)
\end{aligned}
$$

Cadangan premi apabila $x$ meninggal dan $y$ hidup pada akhir tahun ke $-t+1$ :

$$
\begin{aligned}
{ }_{t} V & =R_{y} \times \ddot{a}_{y+t} \\
& =R_{y} \times\left(\frac{N_{y+t}}{D_{y+t}}\right)
\end{aligned}
$$

Formula cadangan premi suku bunga Vasicek memiliki formula yang sama dengan formula cadangan premi suku bunga konstan, perbedaan formula cadangan premi suku bunga tetap dan suku bunga Vasicek adalah faktor diskonto pada suku bunga tetap yaitu $v^{k}$ disubsitusikan oleh $\mathrm{P}(k)$ suku bunga Vasicek. 
Berdasarkan perhitungan cadangan premi asuransi jiwa joint life untuk usia peserta lakilaki 40 tahun dan perempuan 35 tahun dengan lama pembayaran premi sepuluh tahun, maka diperoleh nilai premi suku bunga tetap Rp. 0,1071 dan nilai premi suku bunga Vasicek Rp. 0,1057 . Berdasarkan nilai cadangan premi yang diperoleh, cadangan premi suku bunga Vasicek secara keseluruhan lebih kecil dari pada nilai cadangan premi suku bunga tetap. Hal ini dikarenakan faktor diskonto pada suku bunga Vasicek lebih kecil dari pada suku bunga tetap, oleh karena itu suku bunga Vasicek lebih menguntungkan masyarakat daripada suku bunga tetap karena nilai preminya lebih murah.

\section{Saran}

Pada penelitian selanjutnya disarankan untuk menggunakan suku bunga stokastik model CIR, BDT, Ho-Lee dan lainnya dengan perhitungan secara prospektif.

\section{DAFTAR PUSTAKA}

Dickson, D.C.M., Hardy, M.R. \& Waters, H.R., 2009. Actuarial Mathematics for Life Contingent Risk. New York: Cambridge University Press.

http://bookzz.org./md5/C4ADC30B53F17D 6B9B989D728A56DB11. Diakses 2 Maret 2017.

Futami, T., 1994. Matematika Asuransi Jiwa, Bagian I. Tokyo: Oriental Life Insurance Cultural Development Center.Terjemah dari:Seime Hoken Sugaku Gekan ("92 Revision).

1993. Matematika Asuransi Jiwa, Bagian I. Tokyo: Oriental Life Insurance Cultural Development Center.Terjemah dari:Seime Hoken Sugaku Gekan ("92 Revision).

Matvejevs, A. \& Matvejevs, A., 2001. Insurance Models for Joint Life and Last Survivor Benefit. Informatica, 12(4), Pp.547-558.

Paul, Wand Baschnagel,J. 2013. Stochastic Process From Physics to Finance. London: Springer International Publishing Switzerland. http://bookzz.org/md5/35B3F5BE9F00F83
D27F5DD6A68C4E902. Diakses 19 April 2017.

Sembiring, R.1986. Buku Materi Pokok Asuransi I Modul 1-5.Jakarta: Karunika.

Soffan, R Soffan, Raden Muhamad. 2011. Perhitungan Premi Asuransi Jiwa Berjangka Menggunakan Model Stokastik Tingkat Suku Bunga. Jurnal BIAStatistika Vol.5 No.1, 1-10.

Zetun, S, A, Gupta 2007, A Comparative Study of the Vasicek and the CIR Model of the Short Rate. Germany: Fraunhofer-Institut fur Techno- und Wirtschaftsmathematik. 